\title{
DETECTION OF SALMONELLA SPP. ISOLATED FROM READY-TO-EAT FOOD BY PCR AND CONVENTIONAL METHODS: A COMPARATIVE STUDY
}

\author{
WALAA M. ALI; M.W. ABD AL-AZEEM and SERAGELDEEN SULTAN \\ Department of Microbiology, Fac. Vet. Med., South Valley Univ.
}

Received: 18 September 2017; $\quad$ Accepted: 15 October 2017

\begin{abstract}
Salmonellae are important food-borne pathogens. Infection with Salmonella may not lead to fatal disease, but it may remain localized in the gastrointestinal tract resulting in gastroenteritis or may take a septicemic form that can affect several organ systems causing gastroenteritis, bacteremia and subsequent focal infection. To compare PCR with different conventional methods for identification of Salmonella species, and to determine the virulence of the Salmonella serovars obtained from Ready-to-eat food by investigating the presence of virulence gene, InvA in the chromosomal DNA. A total of 100 clinical samples were collected. These included: 25 beef burger, 25 kofta, 25 hawawshy and 25 liver sandwiches. They were subjected to bacteriological, biochemical examination and PCR amplification assay for virulence gene invA. By comparing the results of PCR using S139 and S141 primers and those of biochemical reactions, it was found that PCR could detect 13 samples as Salmonella isolates that include (9 biochemically positive and 4 biochemically negative). While biochemical reactions could detect 11 samples as Salmonella isolates and when examined by PCR, it excluded 2 samples as non-Salmonella isolates. So, we found that PCR is more specific and more superior to cultural methods and biochemical test for isolation of Salmonella. By comparing the results of PCR and those of serological test, it was found that PCR assay had the same results of serological test, for the strains that were biochemically positive, so the PCR assay were used to confirm the serological results. PCR amplification assay has the ability to detect a wide range of Salmonella species depending on the design of primers targeted to invasion gene operon (InvA gene) of salmonella. In conclusion, PCR technique may provide a valuable, rapid, specific and sensitive laboratory diagnostic test for detection of salmonella DNA in cultures.
\end{abstract}

Key words: Salmonella, PCR, Ready-to-eat food.

\section{INTRODUCTION}

Ready-to-eat (RTE) food is processed foodstuffs which have gained popularity in recent times because they can be ingested without further thermal treatments (Rodriquez et al., 2010). Both fast-food restaurants and street vendors are offering RTE foods. The highly increasing demand for Ready-to-eat food can be illustrated by changing life style affecting food behavior; increasing number of women in work force and limited commitment to food preparation (Borch and Arinder, 2002 and Gudbjornsdottirm et al., 2004). In Egypt, the most ready - to - eat sandwiches sold in street vendors and fast food restaurants are Beef burger, kofta, ElHawawshi and Liver (Kibda) sandwiches (Ayaz et al., 1985). During the last two decades, Salmonella

Corresponding author: Dr. WALAA M. ALI

E-mail address: walaa1286@yahoo.com

Present address: Department of Microbiology, Fac. Vet. Med., South Valley Univ. was considered the most common food borne pathogen in the world due to its increasing incidence (Edwards and Ewing, 1972) and its association with consumption of ready-to-eat meat products. Worldwide, there are about 275 million humans had diarrheal diseases caused by Salmonella (Cabedo et al., 2008). Salmonellosis is one of the most common and widely distributed food-borne diseases and it is the second food-borne disease after campylobacteriosis in Europe (Botti et al., 2013; European Food Safety Authority, 2012). Typhoidal cases are stable with low numbers in developed countries, but non-typhoidal salmonellosis has increased worldwide. Typhoid fever usually causes mortality in 5 to $30 \%$ of typhoid-infected individual in the developing world. The World Health Organization (WHO) estimates 16 to 17 million cases occur annually, resulting in about 600,000 deaths. The mortality rates differ from region to region, but can be as high as 5 to $7 \%$ despite the use of appropriate antibiotic treatment. On the other hand, non-typhoidal cases account for 1.3 billion cases with 3 million deaths. In the United States, approximately 2 to 4 million cases of Salmonella 
gastroenteritis occur with about 500 deaths per year. A more accurate figure of salmonellosis is difficult to determine because normally only large outbreaks are investigated whereas sporadic cases are underreported. (Portillo, 2000; Hanes, 2003; Hu and Kopecko, 2003). Traditional Salmonella detection methods are based on cultures using selective media and the characterization of suspicious colonies by biochemical and serological tests. These methods are generally time-consuming. Therefore, a rapid method is necessary for the identification of Salmonella isolates from clinical specimens (Alvarez et al., 2004). There has been a general move toward molecular methods of Salmonella detection and typing, which are based less on phenotypic features and more on stable genotypic characteristics (Arrach et al., 2008). PCR has become a potentially powerful alternative in microbiological diagnostics due to its simplicity, rapidity, reproducibility, and accuracy (Pickup et al., 2003). InvA gene could be used as specific marker gene for the rapid detection of Salmonella isolates from various biological samples irrespective of sample origin (Das et al., 2012). For these reasons, it was decided to carry out an investigation for PCR amplification assay as a rapid and sensitive alternative test for the detection of Salmonella spp. following isolation and identification by bacteriological and biochemical methods.

\section{MATERIALS AND METHODS}

\section{Collection of samples:-}

A total of one hundred Ready-to-eat sandwiches were collected from different fast-food restaurants and street venders with different sanitation levels. The collected sandwiches include beef burger, kofta, Hawawshy and liver (25 of each). Each collected sample was wrapped in a separate sterile plastic bag, sealed, labeled and kept in an ice box then transferred to the laboratory under complete aseptic conditions without undue delay and examined as quickly as possible. The collected samples were subjected to bacteriological examinations for the detection of Salmonellae (APHA, 2001).

\section{Preparation of samples:-}

At the laboratory the content (meat part) of each sandwich was aseptically and carefully removed then mixed well in a sterile mortar. Isolation and identification of salmonella in each one were detected.

3. Isolation of Salmonella spp.: (ISO-6579, 2002): 3.1. Pre-enrichment in Non- selective liquid media:

Twenty five grams of each prepared sample were taken, cut into small pieces using sterile forceps and scissors and blended for two minutes in sterile blender jar containing $225 \mathrm{ml}$ of $0.1 \%$ sterile buffered peptone water (BPW) as a pre-enrichment broth which recommended by (Edel and Kamplmacher, 1973). Aseptically transfer each blended sample to $500 \mathrm{ml}$ sterile wide-mouth, screwcaped jar and incubated at $37{ }^{\circ} \mathrm{C}$ for $18 \pm 2 \mathrm{hrs}$.

\subsection{Enrichment in selective liquid media:}

$0.1 \mathrm{ml}$ of pre-enrichment culture was transferred into sterile tubes containing $10 \mathrm{ml}$ of Rappaport Vassiliadis broth (RVS) and the tubes were then vortexed and incubated at $41.5^{\circ} \mathrm{C} \pm 1$ for $24 \mathrm{hrs}$. (Rappaport et al., 1956 and Harvey and Price, 1981).

\subsection{Selective plating:}

Xylose lysine desoxychoclate agar (XLD) was used. A loopful of each incubated tube was streaked on (XLD) agar plates and incubated at $37^{\circ} \mathrm{C}$ for $24 \mathrm{hrs}$. After incubation examine the plates for presence of typical colonies of salmonella. Typical colony of salmonella on XLD agar appears as pink colonies with or without black centers.

The suspected colonies were sub-cultured onto nutrient agar plate and incubated at $37^{\circ} \mathrm{C}$ for 24 hours. However, the purified suspected colonies were selected and streaked onto nutrient agar slope for further identification. The purified isolates were identified morphologically, biochemically and serologically.

\section{Identification of Salmonella spp.:- \\ 4.1. Morphological identification:}

4.1.1. staining reaction: (Cruickshank et al., 1975):

Films of pure suspected cultures were stained with Gram's stain and examined microscopically under oil emersion lens. Salmonellae are 2-3 $\mu \mathrm{m}$, pink to red Gram negative short bacilli with rounded end.

\subsubsection{Motility test: (ICMSF, 1978):}

Motility medium was inoculated by the stabbing technique to a depth of $5 \mathrm{~mm}$ and then incubated at $37^{\circ} \mathrm{C}$ for $24-48$ hours. A circular growth from the line of stabbing represented a positive test. Salmonella spp. are motile except Salmonella pullorum and Salmonella gallinarum.

\subsection{Biochemical identification (MacFaddin, 2000):}

\subsubsection{Hydrogen sulphide production test:}

On Triple Sugar Iron (TSI) agar, isolated organisms were stabbed into the bottom of the butt with a needle, and then it was drawn over the slant, for production of a sufficient surface growth. The inoculated tubes were incubated at $37^{\circ} \mathrm{C}$ for $24-48$ hours. Hydrogen sulphide (H2S) production was noted by blacking the medium, while acid formation is indicated by yellow color. 


\subsubsection{Citrate utilization test:}

Slants and butts of Simmon's citrate agar tubes were stabbed from pure cultures and incubated at $37^{\circ} \mathrm{C}$ for 48-96 hours. The development of blue colouration indicated utilization of citrate. Salmonella give positive result.

\subsubsection{Urease test:}

Christensen's urea agar medium was inoculated with suspected isolates and incubated at $37^{\circ} \mathrm{C}$ for 24 hours. Development of pink colour denoted a hydrolysis of urea. Negative tubes were re-examined after further incubation for 24 hours. Salmonella give negative result.

\subsubsection{Lysine iron agar:}

Isolated organisms were stabbed into the bottom of the butt with a needle, and then it was drawn over the slant, for production of a sufficient surface growth. The inoculated tubes were incubated at $37^{\circ} \mathrm{C}$ for 24- 48 hours. Positive reaction was indicated by development of alkaline (purple) color in the slant and alkaline (purple) color in the butt with black coloration.

5. Serological identification and serotyping of salmonella:

Isolates proved biochemically to be Salmonella microorganisms were subjected to serological identification according to Kauffman - White scheme (Kauffman, 1974).

6. Polymerase Chain Reaction (PCR) for detection of salmonella species:

6.1. DNA Extraction using QIA amp kit (Shah et al., 2009):

6.2. Amplification reaction for Salmonella-specific gene (invA) (Shanmugasamy et al., 2011):

The PCR cycling protocol (Thermal cycler) was applied as following:

Initial denaturation at $94^{\circ} \mathrm{C}$ for 60 second.

Denaturation at $94^{\circ} \mathrm{C}$ for 60 second.

Annealing at $64^{\circ} \mathrm{C}$ for 30 second. $\}$ For 35 cycles

Extension at $72^{\circ} \mathrm{C}$ for 30 second.

Followed by a final extension at $72^{\circ} \mathrm{C}$ for $7 \mathrm{~min}$.

6.3. Agarose Gel Electrophoresis and identification of PCR Products: According to (Surzycki, 2000).

\section{RESULTS}

\section{I- Results of the conventional bacteriological} methods:

A-Results of cultural examination:

Table 1: The Incidence of suspected salmonella strains among the different RTE samples

\begin{tabular}{lccccc}
\hline \multirow{2}{*}{ Samples } & $\begin{array}{c}\text { No. of collected } \\
\text { samples }\end{array}$ & \multicolumn{2}{c}{ Positive samples } & \multicolumn{2}{c}{ Negative samples } \\
\cline { 3 - 6 } Beef burger & 25 & No. & $\%$ & No. & $\%$ \\
\hline Kofta & 25 & 7 & $28 \%$ & 18 & $72 \%$ \\
\hline Hawawshy & 25 & 10 & $40 \%$ & 15 & $60 \%$ \\
\hline Liver & 25 & 5 & $20 \%$ & 20 & $80 \%$ \\
\hline Total & 100 & 28 & $28 \%$ & 72 & $76 \%$ \\
\hline
\end{tabular}

\section{B-Results of biochemical identification:}

Table 2: Results of biochemical identification for suspected isolated strains:

\begin{tabular}{lcccccccc}
\hline Samples & $\begin{array}{c}\text { No. of isolates } \\
\text { for biochemical } \\
\text { identification }\end{array}$ & \multicolumn{2}{c}{$\begin{array}{c}\text { Biochemically } \\
\text { +ve isolates }\end{array}$} & \multicolumn{2}{c}{$\begin{array}{c}\text { Biochemically } \\
\text {-ve isolates }\end{array}$} & \multicolumn{2}{c}{ Total } \\
\cline { 2 - 9 } Beef burger & 7 & No. & $\%$ & No. & $\%$ & No. & $\%$ \\
\hline Kofta & 10 & 6 & 21.4 & 4 & 14.3 & 10 & 35.7 \\
\hline Hawawshy & 5 & 1 & 3.6 & 4 & 14.3 & 5 & 17.9 \\
\hline Liver & 6 & 2 & 7.1 & 4 & 14.3 & 6 & 21.4 \\
\hline Total & 28 & 11 & 39.3 & 17 & 60.7 & 28 & 100 \\
\hline
\end{tabular}

II-Results of serological identification: 
Table 3: Results of serological test for identified biochemically isolated strains:

\begin{tabular}{lcccccccc}
\hline Samples & $\begin{array}{c}\text { No. of isolates } \\
\text { for serological } \\
\text { identification }\end{array}$ & \multicolumn{2}{c}{$\begin{array}{c}\text { Serologically } \\
\text { +ve isolates }\end{array}$} & \multicolumn{2}{c}{$\begin{array}{c}\text { Serologically } \\
\text {-ve isolates }\end{array}$} & \multicolumn{2}{c}{ Total } \\
\cline { 3 - 9 } Beef burger & 2 & No. & $\%$ & No. & $\%$ & No. & $\%$ \\
\hline Kofta & 6 & 5 & 45.4 & 1 & 9.1 & 6 & 54.5 \\
\hline Hawawshy & 1 & 1 & 9.1 & 0 & 0 & 1 & 9.1 \\
\hline Liver & 2 & 2 & 18.2 & 0 & 0 & 2 & 18.2 \\
\hline Total & 11 & 9 & 81.8 & 2 & 18.2 & 11 & 100 \\
\hline
\end{tabular}

Table 4: Serotyping of Salmonella isolated and distribution of serotypes among different clinical samples:

\begin{tabular}{lccccc}
\hline $\begin{array}{l}\text { Identified } \\
\text { Strains }\end{array}$ & $\begin{array}{c}\text { Salmonella } \\
\text { Typhimurium }\end{array}$ & $\begin{array}{c}\text { Salmonella } \\
\text { enteritidis }\end{array}$ & $\begin{array}{c}\text { Salmonella } \\
\text { virchow }\end{array}$ & $\begin{array}{c}\text { Salmonella } \\
\text { Haifa }\end{array}$ & Total \\
\hline Beef burger & 1 & 0 & 0 & 0 & 1 \\
\hline Kofta & 1 & 2 & 1 & 1 & 5 \\
\hline Hawawshy & 1 & 0 & 0 & 0 & 1 \\
\hline Liver & 1 & 1 & 1 & 1 & 9 \\
\hline Total & 4 & 3 & & & 0 \\
\hline
\end{tabular}

Table 5: Serogroup and antigenic structures of serologically identified Salmonella strains isolated from the examined samples of RTE sandwiches:

\begin{tabular}{lccc}
\hline Identified strains & Serogroup & \multicolumn{2}{c}{ Antigenic structure } \\
\cline { 3 - 4 } & & $\mathbf{O}$ & H \\
\hline Salmonella typhimurium & B & $1,4,5,12$ & $\mathrm{i}: 1,2$ \\
\hline Salmonella enteritidis & D1 & $1,9,12$ & $\mathrm{~g}:-$ \\
\hline Salmonella Virchow & C1 & $6,7,1,2$ \\
\hline Salmonella Haifa & B & $1,4,5,12$ & $\mathrm{Z} 10: 1,2$ \\
\hline
\end{tabular}

\section{III- Results of PCR:}

A- Results of PCR assay:

Twenty eight strains that were isolated on XLD were taken for PCR assay (11 strains of these were biochemically positive and 17 strains were negative biochemically).

Table 6: Results of PCR assay for isolated Salmonella:

\begin{tabular}{lcccccccc}
\hline Samples & $\begin{array}{c}\text { No. of } \\
\text { Salmonella } \\
\text { Isolates }\end{array}$ & \multicolumn{2}{l}{ PCR +ve isolates } & PCR -ve isolates & \multicolumn{2}{c}{ Total } \\
\cline { 3 - 8 } & 7 & No. & $\%$ & No. & $\%$ & No. & $\%$ \\
\hline Beef burger & 10 & 5 & 17.8 & 5 & 17.8 & 10 & 35.7 \\
\hline Kofta & 5 & 3 & 10.7 & 2 & 7.2 & 5 & 17.9 \\
\hline Hawawshy & 6 & 3 & 10.7 & 3 & 10.7 & 6 & 21.4 \\
\hline Liver & 28 & 13 & 46.4 & 15 & 53.6 & 28 & 100 \\
\hline Total & & & & & & & 7 & \\
\hline
\end{tabular}

Salmonella specific PCR with primers for InvA gene were performed. The results of PCR assay on DNA obtained from the yielded cultures are given in Photo (1) and Photo (2). 


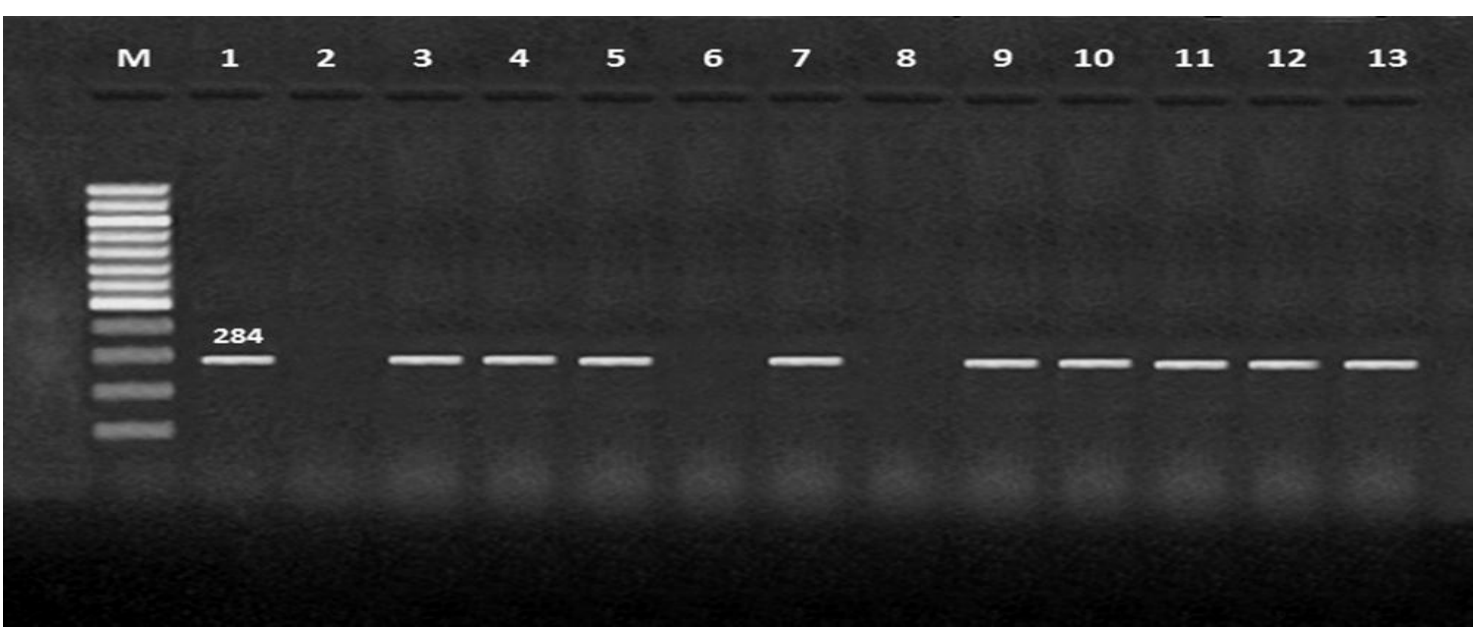

Photo (1): Agarose gel electrophoresis of PCR of $i n v A$ gene (284 bp) for identification and characterization of (11 biochemically positive Salmonella species).

Lane M: 100 bp ladder as molecular size DNA marker.

Lane 1: Control positive Salmonellae for invA gene.

Lane 2: Control negative (No DNA).

Lanes 3, 9 \& 12: Positive $S$. Enteritidis strains for invA gene.

Lane 4: Positive $S$. Virchow strain for invA gene.

Lanes 5, 7, 10 \& 13: Positive $S$. Typhimurium strains for invA gene.

Lane 11: Positive $S$. Haifa strain for invA gene.

Lanes 6 \& 8: Negative Salmonella species.

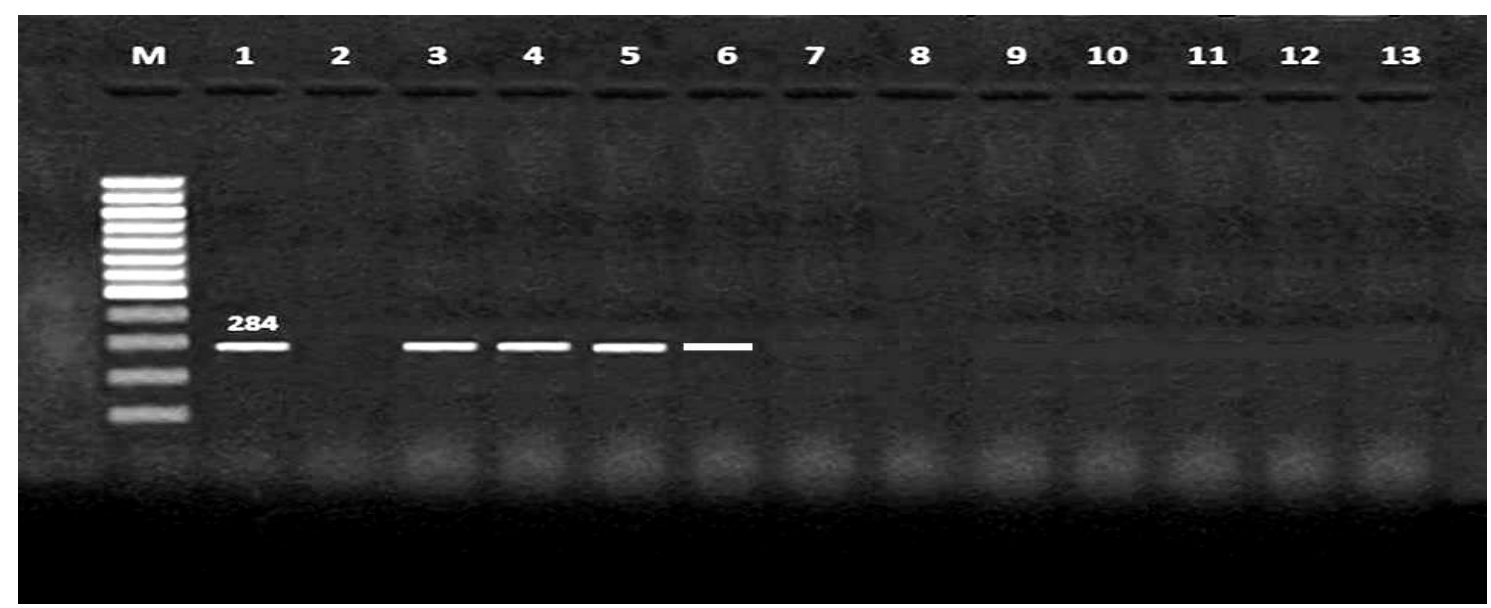

Photo (2): Agarose gel electrophoresis of PCR of invA gene (284 bp) for identification and characterization of (17 biochemically negative Salmonella species).

Lane M: 100 bp ladder as molecular size DNA marker.

Lane 1: Control positive Salmonellae for invA gene.

Lane 2: Control negative (No DNA).

Lanes 3, 4, 5\&6: Positive Salmonella strains for invA gene.

Lanes7,8,9,10,11,12\&13: Negative Salmonella species.

\section{B- Comparison between PCR and biochemical reactions for detection of Salmonella:}

Table 7: Comparison between PCR and biochemical reactions for detection of Salmonella:

\begin{tabular}{cccccccc}
\hline \multirow{2}{*}{ PCR } & \multicolumn{2}{c}{ Biochemical +ve strains } & Biochemical_ve strains & \multicolumn{2}{c}{ Total } \\
\cline { 2 - 7 } & No. & $\%$ & No. & \% & No. & $\%$ \\
\hline Positive & 9 & 32.1 & 4 & 14.3 & 13 & 46.4 \\
\hline Negative & 2 & 7.1 & 13 & 46.4 & 15 & 53.6 \\
\hline Total & 11 & 39.2 & 17 & 60.7 & 28 & 100 \\
\hline
\end{tabular}




\section{C- Comparison between conventional bacteriological examination, biochemical tests, serological tests and} PCR test for detection of Salmonella:

Table 8: Comparison between conventional methods, biochemical tests, serological tests and PCR test for Salmonella isolates:

\begin{tabular}{|c|c|c|c|c|c|c|c|c|c|}
\hline \multirow[t]{2}{*}{ Samples } & \multirow[t]{2}{*}{$\begin{array}{l}\text { No. of } \\
\text { samples }\end{array}$} & \multicolumn{2}{|c|}{$\begin{array}{c}\text { Results of } \\
\text { conventional } \\
\text { methods using } \\
\text { XLD } \\
\text { (+ve isolates) }\end{array}$} & \multicolumn{2}{|c|}{$\begin{array}{c}\text { Results of } \\
\text { biochemical } \\
\text { tests } \\
\text { (+ve isolates) }\end{array}$} & \multicolumn{2}{|c|}{$\begin{array}{c}\text { Result of } \\
\text { Serological } \\
\text { tests } \\
\text { (+ve isolates) }\end{array}$} & \multicolumn{2}{|c|}{$\begin{array}{c}\text { Result of } \\
\text { PCR } \\
\text { (+ve isolates) }\end{array}$} \\
\hline & & No. & $\begin{array}{c}\% \text { from } \\
\text { total }\end{array}$ & No. & $\begin{array}{l}\% \text { from } \\
\text { total }\end{array}$ & No. & $\begin{array}{c}\text { \%from } \\
\text { Total }\end{array}$ & No. & $\begin{array}{c}\text { \%from } \\
\text { Total }\end{array}$ \\
\hline Beef burger & 25 & 7 & 28 & 2 & 8 & 1 & 4 & 2 & 8 \\
\hline Kofta & 25 & 10 & 40 & 6 & 24 & 5 & 20 & 5 & 20 \\
\hline Hawawshy & 25 & 5 & 20 & 1 & 4 & 1 & 4 & 3 & 12 \\
\hline Liver & 25 & 6 & 24 & 2 & 8 & 2 & 8 & 3 & 12 \\
\hline Total & 100 & 28 & 28 & 11 & 11 & 9 & 9 & 13 & 13 \\
\hline
\end{tabular}

\section{DISCUSSION}

Food borne illness associated with the consumption of ready to eat foods has been reported all over the world (FAO, 1988; Garcia et al., 2004; Chumber et al., 2007; Ghosh et al., 2007). Ready to eat food has been implicated in cases of food poisoning or gastroenteritis in human beings (Eley, 1996).

From the results obtained in Table (1) it was evident that Twenty-eight strains of Salmonella spp were isolated from 100 ready-to-eat meat products with a total percentage of (28\%) using XLD agar.

In our study XLD had high efficiency in primary isolation of salmonella from clinical samples. This may be attributed to additional material found in XLD agar e.g. Xylose and Lysine. Xylose is fermented by most enteric organisms except Shigella Spp and Providencia Spp. Lysine is added to identify Salmonella. As xylose is exhausted, Salmonella Spp. organisms decarboxylate lysine causing alkaline conditions which give the colonies red color. Our results agreed with Isenberg, (2004) who reported the high efficiency of XLD agar in primary isolation of Shigella and Salmonella Spp.

From the results obtained in Table (1) it was cleared that although proper cooking temperature sufficient to kill the organism, its presence in ready-to-eat meat and meat products reflect: highly contaminated raw materials, insufficient heating during cooking and post cooking contamination most probably from contaminated workers hands or through using contaminated utensils. In the same time the cross contamination between raw and ready prepared foods is considered as a main source for post cooking contamination (National Academy of Science, 1985)
The obtained results in Table (2) declared that biochemical reactions could detect only 11 strains out of 28 Salmonella isolates, with a percentage of $(39.3 \%)$ as following 2 beef burger samples $(7.1 \%)$, 6 kofta samples $(21.4 \%), 1$ hawawshy sample $(3.6 \%)$ and 2 liver samples (7.1\%). There were $17(60.7 \%)$ negative cases: 5 from beef burger, 4 from kofta, 4 from hawawshy and 4 from liver samples.

The negative results obtained by biochemical reactions may be attributed to the weak metabolic activity or weakly reactive organisms leading to some false-negative reactions, these data were supported by the findings of Elmer et al. (1997).

Serological tests were done after biochemical reaction, since biochemical reactions identified the isolates as salmonella spp. that needs further identification to determine its species. This is in general agreement with the FDA $(1995,2001)$ that recommended serological tests being conducted on isolates that were retained as presumptive Salmonella after urease testing.

The serological identification were performed for the only 11 biochemically $+\mathrm{Ve}$ isolates according to Kauffman - White scheme for the determination of Somatic (O) and flagellar (H) antigens using Salmonella antiserum.

The obtained results in Table (3) declared that serological tests could detect only 9 strains out of 11 Salmonella isolates, with a percentage of $(81.8 \%)$ as following 1 beef burger sample $(9.1 \%), 5 \mathrm{kofta}$ samples $(45.4 \%), 1$ hawawshy sample $(9.1 \%)$ and 2 liver samples (18.2\%). There were 2 (18.2\%) negative cases: 1 from beef burger and 1 from kofta samples.

From the results of Table (4) we found that different serotypes have been isolated from different clinical 
samples. one strain of Salmonella typhimurium was isolated from beef burger samples, one strain of Salmonella typhimurium, two strains of Salmonella enteritidis, one strain of Salmonella virchow, one strain of Salmonella haifa were isolated from kofta samples, one strain of Salmonella typhimurium was isolated from hawawshy samples and one strain of Salmonella typhimurium and one strain of Salmonella enteritidis were isolated from liver samples.

From obtained results in Table (4) it was obvious that Salmonella Typhimurium was the most common serotype isolated from different clinical samples followed by Salmonella enteritidis. This results were agreed with the WHO (1988) that reported that Salmonella typhimurium occurs more, and was more widely distributed than any other serovars, this organism cause severe outbreaks of salmonellosis in all kinds of animals and was frequently the cause of both sporadic cases and outbreaks of gastroenteritis in man all over the world. Also these results were agreed with Herikstad et al. (2002) who stated that Salmonella enterica serovar Typhimurium and Salmonella enterica serovar Enteritidis are the most frequently isolated serovar from food- borne outbreaks throughout the world and with Zhao et al. (2002) who stated that the most common type of Salmonella are typhimurium and enteritidis; they have been causing illness for more than 100 years.

Salmonella enterica serovar virchow (S. virchow) is recognized as one of the more common, invasive Salmonella serotypes (Messer et al., 1997; Willocks et al., 1996) and accounted for $46 \%$ of septicaemia cases caused by Salmonella species (Ashdown and Ryan, 1990).

In addition to bacteremia, S. virchow is capable of causing a range of extra-intestinal infections, which may be associated with serious morbidity and even mortality as Meningitis. (Ashdown and Ryan 1990; Messer et al., 1997).

Kaibu et al. (2005) reported that a case of a 78 years old male who died of food intoxication in Nagasaki 2004 due to Salmonella Haifa.

From the results obtained in Table (5) Salmonella isolates were characterized antigenically and serologically to determine their serogroup and antigenic structure, the isolates were located in 3 serogroups with characteristic antigenic features based on $\mathrm{O}$ and $\mathrm{H}$ antigen.

PCR amplification assay is a new tool for molecular biology; it is so sensitive that a single DNA molecule can be amplified. Presence of salmonella in intensive livestock production presents explicit public health risks in addition to food industry losses. PCR provides a rapid means to monitor specific microorganisms in a variety of samples. This assay is an epidemiologically useful tool to distinguish salmonella spp.

Amplification of DNA sequences unique to an organism using the PCR improves both the speed of detection and the level of sensitivity at which organisms can be detected (Buffone et al., 1991; Ramamurthy et al., 1993) and has been increasingly used to identify several bacterial species from food and clinical samples (Stone et al., 1994). Another advantage is that PCR is not dependent on the utilization of a substrate or the expression of antigens, thereby circumventing phenotypic variations in biochemical patterns and lack of detectable antigens (Hoorfar et al., 1999).

Lampel et al. (2000) and Ferretti et al. (2001) proposed a rapid method with primers for invA gene, which allowed the detection of Salmonella serotypes within a maximum of 12 hours in many clinical samples. In this study, Salmonella genomic DNA was extracted from cultures of the local isolates by using a simple, rapid and reliable protocol based on the boiling.

From the obtained results in Table (6) it is cleared that invasion gene operon, invA was detected in only 13 Salmonella isolates, representing multiple serotypes, out of 28 clinical isolates. This agreed with Das et al. (2012) who reported that invA gene could be used as specific marker gene for the rapid detection of Salmonella isolates from various biological samples irrespective of sample origin.

The chromosomally located invA gene contains sequences unique to Salmonella is found in all known serovars and has been established as an international standard suitable PCR for rapid, less expensive, and sensitive detection of this genus (Rahn et al., 1992).

The obtained result in this study showed that 13strains of Salmonella Spp. were isolated from 100 ready-to-eat meat products with a total percentage of (13\%) using XLD agar. Salmonella was recovered in meat products by many investigators such as Abd El - Aziz (1987) (10\%), Ahmed (1988) (8\%), Siriken et al. (2006) (7\%), El-Mossalami et al. (1989) (6\%), El-Mossalami (2003) (5\%), Torky (2004) (5\%), ElSherif and El-Mossalami (1998) (3.3\%)and Mosupye and Holy (1999) (2\%).

Salmonella spp. was isolated from 2 beef burger samples with a percentage (8\%). This obtained results was higher than those recorded by Usama, Maha (2009) (2.5\%), Mohamed, Enas (2011) (5\%), Soliman, 1988 (5\%), El-Mossalami (1989) (6\%) and Fathi and Thabet (2001) (6\%). But the results in this 
study were lower than those obtained by Badrie et al. (2003) who found that (18.5\%) of beef burger samples were positive for salmonella, Fathi et al. (1994) who isolate salmonella from $(15.8 \%)$ of beef burger samples, also Abd El Fath, Rabab (2015) who isolated Salmonella from $(13.33 \%)$ of examined samples of beef burger and Abou-zaid et al. (2001) who isolated Salmonella from (11.6\%) of ready-toeat beef burger. Soliman et al. (2002) detected Salmonella in (10\%) of ready-to-eat beef burger. In contrast Duitschaever et al. (1977); Karim, (1977); El-sherbeeny et al. (1985); Youssef et al., (1999); Ebraheem, (2001); Chung et al. (2003); ElMossalami, (2003) and Zaki, (2003) failed to isolate Salmonella spp. from RTE beef burger.

Salmonella spp. was isolated from 5 Kofta samples with a percentage of $(20 \%)$. The obtained result was higher than those recorded by Hassan, Shereen (2009) (13.33\%), Al-kour (2001) (12\%), Soliman, 1988 (10\%), Shaltout et al. (2013) (8\%), ElMossalami (2003) (5\%), Usama, Maha (2009) $(2.5 \%)$. Also the obtained results were lower than those obtained by Hassanin et al. (2014) (33.3\%) and Abd El Fath, Rabab (2015) (26.67\%).

On the otherside, some investigators failed to detect salmonella in kofta samples as Hassan (1986); Tolba (1994) Hussein (1996); Ebraheem, (2001); Küplül et al. (2003); Abd El-Aziz, Doaa (2004); Al-Mutairi (2011) and Mohamed, Enas (2011).

In the examined hawawshy samples, Salmonella spp. was isolated from 3 samples $(12 \%)$ as present in table (6). These results were lower than those obtained by Hassanin et al. (2014) which isolate Salmonella from $(40 \%)$ of examined samples. Also our results for hawawshy disagree with those reported by Ebraheem, 2001; El-Mossalami, 2003 and Ismail-Soad (2006). They recorded negative results of Salmonella spp. in the examined hawawshy sandwiches.

Salmonella spp. was isolated from 3 Liver samples with a percentage of $(12 \%)$. This data were higher than those obtained by Abd-El-Malek (2014) who isolates Salmonella typhimurium from $7 \%$ of examined samples. On the contrary Abou, (1995); Ebraheem, (2001) and Büyüky rük, (2014) failed to isolate salmonella from the examined samples.

The obtained results in Table (7) declared comparison between the results of PCR and those of biochemical reactions for detection of Salmonella. It was found that PCR could detect 13 samples as Salmonella isolates that include ( 9 biochemically positive and 4 biochemically negative). While biochemical reactions could detect 11 samples as Salmonella isolates and when examined by PCR, it excluded 2 samples as non-Salmonella isolates. So, we found that PCR is more specific than conventional method, because the conventional methods for Salmonella spp. have very poor specificity, and there were numerous false- positive results Dusch and Altwegg (1995); Perez et al. (2003).

Oliveira et al. (2003) reported that PCR assay using the invA primers specific for Salmonella spp. considerably decreased the number of false-negative results which commonly occur in diagnostic laboratories.

The obtained results in Table (8) declared comparison between the results of PCR and those of biochemical reactions, serological reactions and cultural methods for detection of Salmonella. It was found that PCR assay were more superior to cultural methods and biochemical test for isolation of Salmonella. While PCR assay had the same results of serological test, for the strains that were biochemically positive, so the PCR assay were used to confirm the serological results.

These results agreed with Sallam et al. (2014) who mentioned that the higher prevalence of Salmonella positive samples that were obtained by PCR in the present study in comparison with that of cultural conventional method indicated that PCR is more sensitive and reliable than the phenotypic based culture method

From our study, we can conclude that the identification of Salmonella should not be based on the conventional bacteriological methods only, but also on molecular methods.

The culture techniques are universally recognized as the standard methods for the detection of bacterial pathogens, such as salmonella in food stuffs. These techniques generally take longer time and are less sensitive compared to PCR based methods.

In conclusion, identification of Salmonella and screening of invA gene through PCR based procedures can have major benefit in public health specifically for rapid diagnosis, epidemiological investigations, ideal vaccine, development of treatment, and prophylactic strategies for salmonellosis.

\section{REFERENCES}

Abd El-Aziz, A.T. (1987): Microbial load of some meat products as influenced by the hygienic status of the product plant. M.V.Sc., Thesis, Fac. Vet. Med., Cairo University, Egypt.

Abd El-Aziz, Doaa M. (2004): Microbiological and chemical hazards of some meat products. M V Sc., Thesis. Fac. Vet. Med., Assuit University. 
Abd El Fath, Rabab, R. (2015): Bacteriological status of some ready to eat meat and poultry meat meals in benha city. M.V.Sc. Thesis Fac. of Vet. Med., Moshtohor, Benha University.

Abd-El-Malek, A.M. (2014): Microbiological Quality of Ready-to-Eat Liver Sandwiches (Kibda). Global Veterinaria, 13(6): 1097-1102.

Abou, E.A. (1995): Bacteriological quality of ready to eat meals. J Egypt Public Health Assoc., 70: 627-41.

Abou-zaid, M.; Amira, E.; Hashin, M. and Ahmed, A. (2001): Bacteriological status and safety of RTE Street vended food in Giza governorate. Egypt Vet. Med. 61, 4:79-88.

Ahmed, S. (1988): Salmonella in locally manufactured meat products. M.V.Sc., Thesis, Fac. Vet. Med., Cairo University, Egypt.

Al-Kour, M.S. (2001): Microbiological status of meat and some meat products in northern Jordan. M.V.Sc. Thesis, Fac. Vet. Med.; Jordan University of Science and Technology.

Al-Mutairi, M.F.(2011): The Incidence of Enterobacteriaceae Causing Food Poisoning in Some Meat Products. Advance Journal of Food Science and Technology, 3(2): 116-121.

APHA "American Public Health Association" (2001): Compendium of Methods for Microbiological Examination of Foods. Washington, DC, USA.

Alvarez, J.; Sota, M.; Vivanco, A.B.; Perales, I.; Cisterna, R.; Rementeria, A. and Garaizar, J. (2004): Development of a Multiplex PCR Technique for Detection and Epidemiological Typing of Salmonella in Human Clinical Samples. J. Clin. Microbiol.42(4):1734-1738.

Arrach, N.; Porwollik, S.; Cheng, P.; Cho, A.; Long, F.; Choi, S. and McClelland, M. (2008): Salmonella Serovar Identification Using PCRBased Detection of Gene Presence and Absence. J. Clin. Microbiol. 46(8): 25812589.

Ashdown, L.R. and Ryan, P.J. (1990): Invasive disease due to Salmonella virchow: a north Queensland problem. Med J Aust ,153: 330332, 334-335.

Ayaz, M.; Othman, R.; Bahareth, T.; Al. Sogair, A. and Sawaya, W.N. (1985): Microbiological quality of shawerma in Saudia Arabia. Food Prot, 48, 10:8 11

Badrie, N.; Joseph, A. and Chen, A. (2003): An observational study of food safety practices by street vendors and microbiological quality of street-purchased hamburger beef patties in Trinidad, West Indies. Internet Journal of Food Safety, 3:25-31.

Borch, E. and Arinder, P. (2002): Bacteriological safety issues in red meat\& ready to eat meat products, as well as control measures. Meat Sci., 62:381-390.
Botti, V.; Navillod, F.V.; Domenis, L.; Orusa, R.; Pepe, E.; Robetto, S. and Guidetti, C. (2013): Salmonella spp. and antibiotic-resistant strains in wild mammals and birds in north-western Italy from 2002 to 2010 . Veterinaria Italiana, 49(2):195-202.

Buffone, G.J.; Demmler, G.J.; Schimbor, C.M. and Greer, J. (1991): Improved amplification of cytomegalovirus DNA from urine after purification of DNA with glass beads. Clinical Chemestry 37, 1945-1949.

Büyükyörük, S.; Devrim, B.; Ergun, Ö.G.; Filiz, K. and Pelin, K. (2014): Microbiological evaluation of ready-to-eat sandwiches served near hospitals and schools. Ankara Üniv Vet Fak Derg., 61: 193-198.

Cabedo, L.; Picart, I.; Barrot, L.; Teixidó, I. and Canelles, A. (2008): Prevalence of Listeria monocytogenes and Salmonella in ready-toeat food in Catalonia, Spain. J. Food Prot. 71:855-859.

Chumber, S.; Kaushik, K. and Savy, S, (2007): Bacteriological analysis of street foods in Pune, Indian. J.Public Health 51(2): 114-116.

Chung, Y.H.; Kim, S.Y. and Chang, Y.H. (2003): Prevalence and antibiotic susceptibility of salmonella isolated from foods in Korea from 1993 to 2001. Journal of food protection, 66(7): 1154-1157.

Cruickshank, R.; Duguid, J.P.; Marmion, B.P. and Swain, R.A. (1975): The Practice of Medical Microbiology, $12^{\text {th }}$ ed., vol. II. Churchill living stone, Edinburg, London and New York

Das, A.; Hari, S.S.; Shalini, U.; Ganeshkumar, A. and Karthikeyan, M. (2012): Molecular Characterisation of Salmonella enterica serovar typhi isolated from typhoidal humans. Malaysian Journal of Microbiology, Vol 8 (3), pp. 148-155.

Duitschaever, C.; Bullock, D. and Arnott, D. (1977): Bacteriological evaluation of retail ground beef, frozen beef patties, and cook hamburger. J. Food Prot., 40:378.

Dusch, H. and Altwegg, M. (1995): Evaluation of five new plating media for isolation of Salmonella species. J. Clin.Microbiol. 33:802-804

Ebraheem, Ghada, M. (2001): Ready-to-eat meat sandwiches as a source of potential pathogens in Assiut city. M.V. Sc., thesis, Fac. Vet. Med. Assuit University.

Edel, W. and Kamplmacher, E. (1973): Salmonella isolation in nine European laboratories using standardized technique. Bull. of World Health Organization.

Edwards, P.R. and Ewing, W.H. (1972): Identification of Enterobacteriaceae. Minneapolis, Burgess. Publ. Co. Atlanta, U.S.A. 
Eley, A.R. (1996): Microbial Food Poisoning. $2^{\text {nd }}$ ed., Chapman \& Hall, London, UK.

Elmer, W.K.; Stephen, D.A.; William, M.J.; Paul, C.S. and Washington, C.W. (1997): Color atlas and textbook of diagnostic microbiology, $5^{\text {th }}$ edition. Lippincott-Raven publishers, Philadelphia, New York.

El-Mossalami, E.E.; Safwat, A.A.S.; Abdel-Rahim, J. and El-Sawah, H. (1989): Salmonella in locally produced meat products. J. Egypt. Vet. Med. Assoc., 49(1-2): 99-108.

El-Mossalami, E.K. (2003): Risk assessment of ready prepared meat products. Ph. D., Thesis, Fac. Vet. Med., Cairo Univ.

El-Sherbeeny, M.R.; Saddik, M.F and Bryan, F. (1985): Microbiological profiles of food served by street vendors in Egypt. International J. Food Microbiol. 216: 355.

El-Sherif, A.M. and El-Mossalami, M.K. (1998): Rombach agar as a new differential medium for the indentification of some enteric pathogens in meat products. Z. Lebensm. Ulters. Forsch. A. 207 (2): 160 - 163.

European Food Safety Authority, European Center for Disease Prevention and Control; the European Union. (2012): Summary Report on Trends and Sourses of Zoonoses, Zoonotic Agents and Food-borne Outbreaks in 2010. EFSA Journal, 10:2597-2600.

FAO (1988): Street foods. Reoprt of FAO expert consultation, Yogyakarta, Indonesia. FAO Rome, Food Nutr. Paper 1988 No.46.

Fathi, S.M.; El-Khateib, T.; Moustafa, S. and Hassanein, K. (1994): Salmonella and Enteropathogenic Escherichia coli in some locally manufactured meat products. Assuit. Vet. Med. J., 31(61): 190-199.

Fathi, S.A. and Thabet, A. (2001): Incidence of Salmonella and E.coli in packed meal products sold in Assuit city. Assuit Vet. Med. J., 64(91):187-199.

FDA: Center for Food Safety and Applied Nutrition (1995): FDA Bacteriological Analytical Manual. Arlington, VA: Association of Official Analytical Chemists.

FDA: Center for Food Safety and Applied Nutrition (2001): FDA Bacteriological Analytical Manual, $8^{\text {th }}$ ed. Washington, DC: US Food and Drug Administration (http:// www.vm.cfsan.fda.gov/_ebam/bam-5.html).

Ferretti, R.; Mannazzu, L.; Cocolin, L.; Comi, G. and Clementi, F. (2001): Twelve-hours PCRbased method for detection of Salmonella spp. in food. Appl. Environ. Microbiol., 74: 977978.

Garcia, T.; Sancedo, C.; Ayala, B.; Thompson, M. and Gutierrez, L. (2004): Prevalence of E. coli and Salmonella spp. in street vended food of open markets (tianguis) and general hygienic and trading practices in Mexico City. J. Epidemiol. Infect., 132:1181-1184.

Ghosh, M.; Wahi, S. and Ganguli, K. (2007): Prevalence of enterotoxigenic Staphylococcus aureus and Shigella spp. in some raw street vended Indian foods. Int. J. Environ. Health Res. 17(2): 151-6.

Gudbjornsdottirm, B.; Suihko, M.; Gustavsson, P.; Thorkelsson, G.; Salo, S.; Sjoberg, A.; Niclassen, P. and Bredholt, S. (2004): The incidence of L.monocytogenes in meat, poultry and seafood plants in Nordic countries. Food Microbiol, 21:217-225.

Hanes, D. (2003): Non-typhoid Salmonella. In Henegariu, O.; Heerema, N. A.; Dloughy, S. R.; Vance, G. H and Vogt, P. H. (Eds.). International handbook of foodborne pathogens, p. 137-149. New York: Marcel Dekker, Inc.

Harvey, R.W. and Price, T.H. (1981): Comparison of Selenite F, Muller Kauffmann Tetrathionate and Rappaport medium for Salmonella isolation from chicken giblets after preenrichment in buffered peptone water. J. Hyg. Camb, 87:219.

Hassan, E. (1986): Microbiological quality of readyto-eat meat meals in air catering. M.V.Sc. Thesis Fac. of Vet. Med. Cairo University.

Hassan, Shereen, H.G. (2009): Microbiological status of some ready to eat meat products. M.V.Sc. Thesis Fac. of Vet. Med., Moshtohor, Benha University.

Hassanin, F.; Reham, A.A.; Shawky, N. and Gomaa, W. (2014): Incidence of Escherichia coli and Salmonella in Ready to eat Foods. Benha Vet. Med. J., 27(1): 84-91.

Herikstad, H.; Motarjemi, Y. and Tauxe, R.V. (2002): Salmonella surveillance: a global survey of public health serotyping. Epidemiology and Infection, Vol. 129, pp. 18.

Hoorfar, J.; Baggesen, D.L. and Porting, P.H. (1999): A PCR-based strategy for simple and rapid identification of rough presumptive Salmonella isolates. Journal of Microbiological Methods 35, 7-84.

$H u$, L. and Kopecko, D.J. (2003): Typhoid Salmonella. In Millotis, M. D. and Bier, J. W. (Eds.). International handbook of foodborne pathogens, p. 151-165. New York: Marcel Dekker, Inc.

Hussein, M. (1996): Microbial evaluation of some meat meals of Assiut restaurants. M.V.Sc. Thesis, Fac. of Vet. Medicine, Assiut University.

ICMSF "International Commission on Microbiology Specifications for Foods" (1978): Microorganisms in Food 1 their significance and methods of enumeration, $2^{\text {nd }}$ Ed. University of Toronto press, Canada. 
Isenberg, H.D. (ed.). (2004): Clinical microbiology procedures handbook, Vol. 1,2 and $3,2^{\text {nd }}$ ed. American Society for Microbiology, Washington, D. C.

Ismail- Soad. (2006): Microbiological quality of hawawshi consumed in Ismailia, Egypt. J. Food Safety, 26: 251-263.

$I S O$

"International Organization of Standardization" (2002): International Organization for Standardization. No.6579. Microbiology of food and animal feeding stuffs Horizontal methods for detection of Salmonella species.

Kaibu, H.; Higashine, H.; Iida, K.; Ueki, S. and Ehara, H. (2005): A fatal food intoxication case due to Salmonella Haifa. Japanese journal of infectious diseases, 58(3), 192.

Karim, G. (1977): Bacteriological quality of raw and cooked hamburger at the retail level in Tahran. J.food prot., 40, (8):560.

Kauffmann, G. (1974): Kauffmann white scheme. J. Acta. Path. Microbiol. Sci. 61:385.

Küplül, Ö.; Sarimehmetoğlu, B. and Oral, N. (2003). The microbiological quality of ciğ köfte sold in Ankara. Turk. J. Vet. Amin. Sci., 27: 325329.

Lampel, K.A.; Orlandi, P.A. and Kornegay, L. (2000): Improved template preparation for detection of food-borne bacterial pathogens. Appl. Environ Microbiol., 66: 4539- 4542.

Macfaddin, J. F. (2000): Biochemical tests for identification medical bacteria. Warery press, INC. Baltimore, Md. 21202 USA.

Messer, R.D.; Warnock, T.H.; Heazlewood, R.J. and Hanna, J.N. (1997): Salmonella meningitis in children in far north Queensland. J Paediatr Child Health, 33: 535-538.

Mohamed, Enas A.A. (2011): Microbial and chemical evaluation of fast foods. M.V. Sc., Thesis. Fac. Vet. Med., Moshtohor, Benha University.

Mosupye, F.M. and von Holy, A. (1999): Microbiological quality and safety of readyto-eat street-vended foods in Johannesburg, South Africa. Journal of Food Protection $®$, 62(11): 1278-1284.

National Academy of Science "NAS" (1985): An evaluation of the role of microbiological criteria for foods and food ingredients. National Academy Press, Washington D.C.

Oliveira, S.D.; Rodenbusch, C.R.; Ce, M.C.; Rocha, S.L.S. and Canal, C.W. (2003): Evaluation of selective and non-selective enrichment PCR. Letters in Applied Microbiology, 36 (4): 217 221.

Perez, J.M.; Cavalli, P.; Roure, C.; Renac, R.; Gille, Y. and Freydiere, A.M. (2003): Comparison of Four Chromogenic Media and Hektoen Agar for Detection and Presumptive
Identification of Salmonella Strains in Human Stools. J. Clin. Microbiol.41(3):1130-1134.

Pickup, R.W.; Rhodes, G. and Hermon-Taylor, J. (2003): Monitoring bacterial pathogens in the environment: advantages of a multilayered approach. Curr. Opin. Biotechnol. 14:319325

Portillo, F.G. (2000): Molecular and cellular biology of Salmonella pathogenesis. In Cary, J. W. and Bhatnagar, D. (Eds.), Microbial foodborne diseases: Mechanisms of pathogenesis and toxin synthesis, p. 3-34). United States of America: Technomic Publishing Company,Inc.

Rahn, K.; De Grandis, S.A.; Clarke, R.C.; McEwen, S.A.; Galan, J.E.; Ginocchio, C.; Curtiss III, R. and Gyles, C.L. (1992): Amplification of an invA gene sequence of Salmonalla typhimurium by polymerase chain reaction as a specific method of detection of Salmonella. Mol. Cell. Probes., 6(4): 271- 279.

Ramamurthy, T.; Pal, A.; Bag, P.K.; Bhattacharya, S.K.; Nair, G.B.; Kurozano, H.; Yamasaki, S., Shirai, H.; Takeda, T.; Uesaka, Y.; Horigome, $K$. and Takeda, Y. (1993): Detection of cholera toxin gene in stool specimens by polymerase chain reaction: comparison with bead enzyme-linked immunosorbent assay and culture method for laboratory diagnosis of cholera. Journal of Clinical Microbiology 31, 3068-3070.

Rappaport, E.; Kontortt, N. and Navn, B. (1956): A new enrichment medium for certain Salmnellae. J. Clin. Path. 9:261.

Rodríguez-Cavallini, E.; Rodríguez, C.; Gamboa, M.M. and Arias, M.L. (2010): Microbiological evaluation of ready-to-eat foods manufactured by small Costa Rican industries. Archivos latinoamericanos de nutricion, 60(2): 179-183.

Sallam, K.I.; Mohammed, M.A.; Hassan, M.A. and Tamura, T. (2014): Prevalence, molecular identification and antimicrobial resistance profile of Salmonella serovars isolated from retail beef products in Mansoura, Egypt. Food control, 38, 209-214.

Shah, D.; Shringi, S.; Besser, T. and Call, D. (2009): Molecular detection of foodborne pathogens, Boca Raton: CRC Press, In Liu, D. (Ed).Taylor \& Francis group, Florida, USA, Pp. 369-389.

Shaltout, F.A.; Amani, M.S.; Mahmoud, A.H. and Abd Elraheem, K.A. (2013): Bacterial aspect of cooked meat and edible offal at street vendors level. Benha veterinary medical journal. 24(1):320-328.

Shanmugasamy, M.; Velayutham, T. and Rajeswar, J. (2011): Inv A gene specific PCR for detection of Salmonella from broilers. Vet. World, 4 (12): 562-564. 
Siriken, B.; Pamuk, S.; Ozaku, C.; Gedikoghe, S. and Eyigor, M. (2006): A note on the incidences of Salmonella species, Listeria species and E.coli $\mathrm{O} 157: \mathrm{H} 7$ serotypes in Turkish sausage (soudjouck). Meat Sci., 72(1): 7.

Soliman, M. (1988): Sanitary status of ready-to-eat meat product, and fishes. M.V.Sc, Thesis, Fac. of Vet. Med. Cairo Univ.

Soliman, M.; Abdel Monem, K. and Saad, S.M. (2002): Microbiological quality of ready-toeat meat products and fishes in urban and rural areas. J. Egypt Vet. Med. Ass., 62(6a): 39-51.

Stone, G.G.; Oberst, R.D.; Hays, M.P.; McVey, S. and Chengappa, M.M. (1994): Detection of Salmonella serovars from clinical samples by enrichment broth cultivation-PCR procedure. Journal of Clinical Microbiology 32, 17421749.

Surzycki, S. (editor) (2000): Basic technique in Molecular Biology. ( $1^{\text {st }}$ edition). SpringerVerlag New York, LLC.ISBN13:9783540666783.

Tolba, K.S. (1994): Microflora in locally processed frozen meat. Vet. Med.J. Giza, 42(2):99.

Torky, A.A.S. (2004): Trials for inhibition of some food poisoning microorganisms in meat products. Ph. D., Thesis, Fac. Vet. Med., Cairo University, Egypt.
Usama, Maha, M. (2009): The incidence and levels of Salmonella and some emerging bacterial pathogens in the catering environment in Assiut. M.v. Sc., Thesis. Fac. Vet. Med., Assiut University.

WHO "World Health Organization" (1988): Salmonellosis control. The role of animal and product hygiene. Report of WHO expert committee on Salmonellosis control Barking Essex, UK.

Willocks, L.J.; Morgan, D.; Sufi, F.; Ward, L.R. and Patrick, H.E. (1996): Salmonella virchow PT 26 infection in England and Wales: a case control study investigating an increase in cases during1994. Epidemiol Infect; 117: 3541.

Youssef, H.; Nassar, A.; Hassanein, K. and AbdAlla, M. (1999): Predominance of some food poisoning microorganisms in meat products. $5^{\text {th }}$ Sci. Cong., Egyptian Society for cattle Diseases, 28-30 Nov-1999, Assiut, Egypt. pp. 211-215.

Zaki, E.M. (2003): Risk assessment of ready prepared meat products. Ph. D. Thesis, Meat Hygiene. Fac. Vet. Med., Cairo University.

Zhao, T.; Doyle, M.; Fedorka, G.; Zhao, P. and Ladely, S. (2002): Occurance of Salmonella enterica serotype typhimurium DT104 in ground beef. J. Food., 65,(2):403-407.

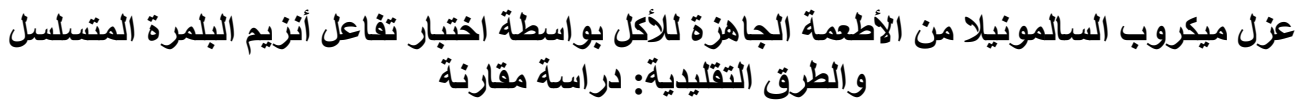

\section{ولاء محمد على ، محد وائل عبل العظيم ، سراج الدين أحد سلطان \\ Email: walaa_1286@yahoo.com Assiut University web-site:www.aun.edu.eg}

يعتبر ميكروب السالمونيلا من الميكروبات الممرضة الهامة التى تتنقل عن طريق الطعام. قد لأيؤدى العدوى بميكروب السالمونيلا

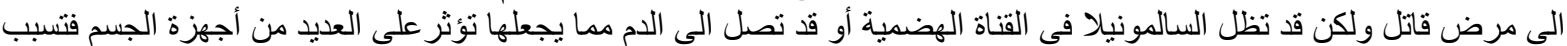

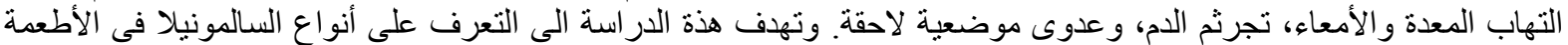

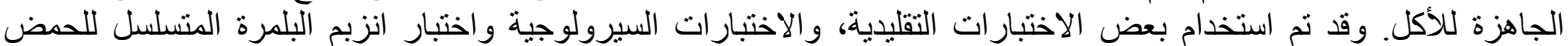

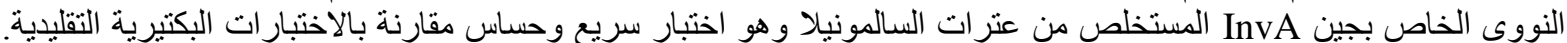

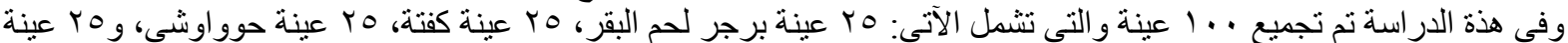

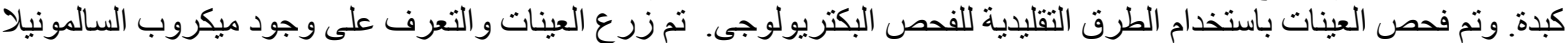

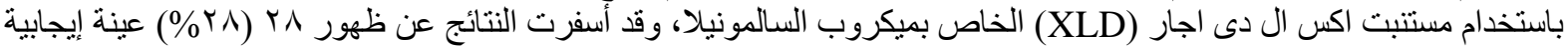

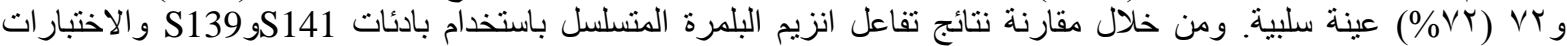

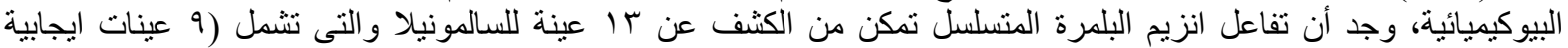

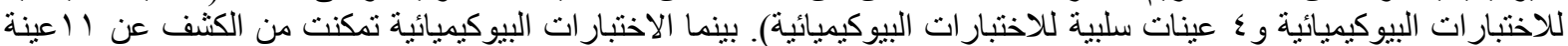

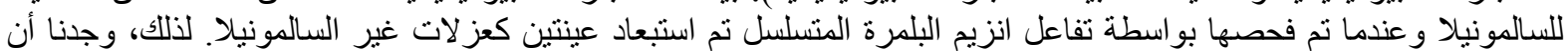

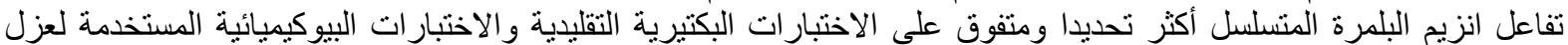

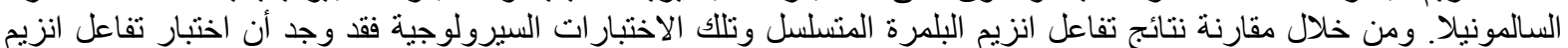

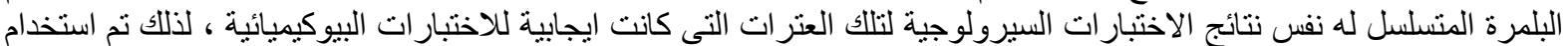

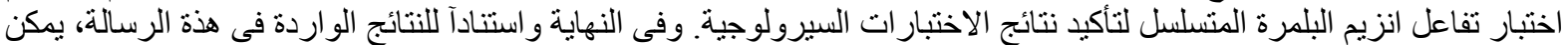

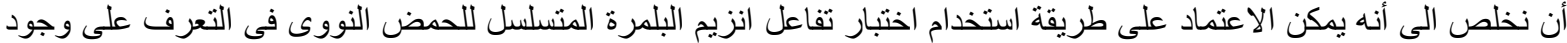

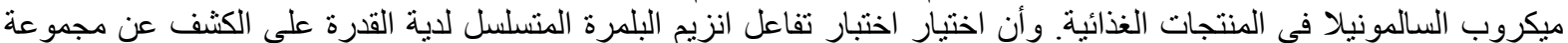

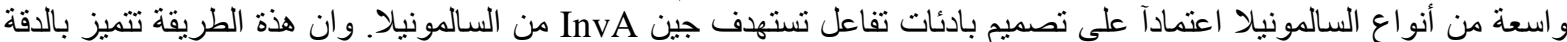

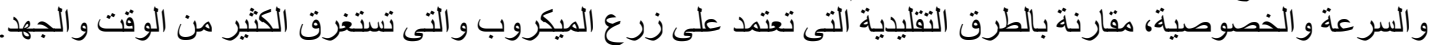

